Research Article

\title{
Potential of Duckweed (Lemna minor) for the Phytoremediation of Landfill Leachate
}

\author{
M. K. Daud (D), ${ }^{1,2}$ Shafaqat Ali $\left(\mathbb{D},{ }^{3}\right.$ Zohaib Abbas, ${ }^{3}$ Ihsan Elahi Zaheer, ${ }^{3}$ \\ Muhammad Ahsan Riaz, ${ }^{3}$ Afifa Malik, ${ }^{4}$ Afzal Hussain, ${ }^{3}$ Muhammad Rizwan, ${ }^{3}$ \\ Muhammad Zia-ur-Rehman, ${ }^{5}$ and Shui Jin Zhu ${ }^{1}{ }^{1}$ \\ ${ }^{1}$ Department of Agronomy, College of Agriculture and Biotechnology, Zhejiang University, Zijingang Campus, \\ Hangzhou 310058, China \\ ${ }^{2}$ Department of Biotechnology and Genetic Engineering, Kohat University of Science and Technology, Kohat 26000, Pakistan \\ ${ }^{3}$ Department of Environmental Sciences and Engineering, Government College University, Allama Iqbal Road, \\ Faisalabad 38000, Pakistan \\ ${ }^{4}$ Sustainable Development Study Center, Government College University, Lahore, Pakistan \\ ${ }^{5}$ Institute of Soil \& Environmental Sciences, University of Agriculture, Faisalabad, Pakistan
}

Correspondence should be addressed to Shafaqat Ali; shafaqataligill@gcuf.edu.pk and Shui Jin Zhu; shjzhu@zju.edu.cn

Received 9 May 2018; Revised 8 October 2018; Accepted 22 October 2018; Published 2 December 2018

Guest Editor: Gassan Hodaifa

Copyright (c) 2018 M. K. Daud et al. This is an open access article distributed under the Creative Commons Attribution License, which permits unrestricted use, distribution, and reproduction in any medium, provided the original work is properly cited.

Phytoextraction of zinc, copper, lead, iron, and nickel from landfill leachate by duckweed (L. minor) was investigated every 3 days over a period of 2 weeks. Bioconcentration factor and removal efficiency were also calculated. Results of this study proved that $L$. minor significantly reduced the concentration of heavy metals in landfill leachate. Removal efficiency of $L$. minor, for all the metals, from landfill leachate was more than $70 \%$ with the maximum value for copper (91\%). Reduction in chemical oxygen demand (COD) and biological oxygen demand (BOD) was observed by $39 \%$ and $47 \%$, respectively. However, other physiochemical parameters like $\mathrm{pH}$, total suspended solids, (TSS) and total dissolved solids (TDS) were reduced by $13 \%$, 33\%, and $41 \%$, respectively. The value of bioconcentration factor (BCF) was less than 1 with the maximum figure for copper (0.84) and lead (0.81), showing that the plant is a moderate accumulator for these heavy metals. Duckweed (L. minor) appeared as a sustainable alternative candidate and is recommended for the treatment of landfill leachate waste water contaminants.

\section{Introduction}

Ever-increasing population and expansion of industrial activities along with changing lifestyle gave rise to exponential generation of solid waste over the last few years [1]. Therefore, management of municipal solid waste is of utmost importance under current scenario [2]. Feasible and ideal options for the management of municipal solid waste (MSW) at low cost are hard to decide because of diverse considerations [3]. Landfilling is the most acceptable management option for waste disposal in Third World countries. Technical feasibility, low operational cost, less supervision, and simplicity make landfilling the most preferred method for the management of MSW [4]. Degradation of solid waste takes place due to physicochemical changes occurring in the solid waste and matrix of the landfill soil. Landfill leachate, assisted by rainwater and biochemical, physical, and chemical reactions, percolates all the way through the matrix of solid waste. Quality and quantity of leachate depends upon the weather discrepancies, age of landfill, precipitation, and amount/type of solid waste composition [5]. While passing through the waste mass, leachate is polluted with toxic substances and heavy metals [6]. In leachate, the major sources of toxic metals are electronic waste, dyes, pesticides, batteries, and fluorescent lamps [7].

Heavy metal solubility and mobility is highly dependent on the age of landfill, $\mathrm{pH}$, and ratio of organic and inorganic substances [8]. Acid formation at low $\mathrm{pH}$ is considered as the most deliberate phase which boosts up the occurrence of 
high concentration of toxic metals in landfill leachate [9]. Heavy metals are among the major environmental contaminants because of their toxic effects, ability to accumulate in the aquatic system, and nonbiodegradable nature [10]. Landfill leachate is thus regarded as a major environmental hazard which pollutes the surrounding environment affecting local biota, groundwater, and other aquatic systems [5]. Similarly presence of organic parameters like BOD, $\mathrm{COD}$, and $\mathrm{pH}$ are also among complicated parameters in landfill leachate. Higher fractions of these organics are primarily more challenging as they are less biodegradable in nature and have selective toxicity for biological process [11]. Hence, selection of suitable methods for the treatment of the landfill leachate, before its final disposal into any water body, is an important step to avoid the environmental degradation.

Traditional heavy metals remediation techniques like ion exchange, filtration, and adsorption are not cost effective and may adversely affect the aquatic ecosystem [12]. Use of plants in purification process is called phytoremediation, and it has gained attention as a suitable option for the treatment of landfill leachate $[6,13]$. In case of heavy metals, phytoremediation is a self-sustaining and economical alternative treatment technology [14]. During the last two decades, phytoremediation has attained substantial significance and the discovery of hyperaccumulator plants made it more promising because of their ability to accumulate high amount of heavy metals in aerial parts of the body $[15,16]$. Ideally, the plants used for phytoremediation should have the ability to produce high biomass, survive in extremely toxic environment, and accumulate the contaminants in high concentration. Degradation of different contaminants depends upon the selection of phytoremediation technique and type of the particular contaminants [17]. Plants act as host for endophytic bacteria by providing nutrients and offering protection against physical environment. These symbiotic relations promote the growth and competitiveness of plants to respond to the external stresses such as nutrients and heavy metals [18].

Recent studies have described some aquatic plant species best suited for the remediation of heavy metals like $\mathrm{Cu}, \mathrm{Zn}, \mathrm{Fe}, \mathrm{Cd}, \mathrm{Pb}, \mathrm{Cr}, \mathrm{Hg}$, and $\mathrm{Ni}[19,20]$. Aquatic plants like Eichhornia crassipes, Azolla filiculoides, Pistia stratiotes, Hydrilla verticillata, Typha domingensis, Salvinia Cucullata, Azolla caroliniana, Azolla pinnata, Lemna minor, Lemna aequinoctialis, Lemna gibba, and Spirodela polyrhiza are suitable aquatic plants for the removal of heavy metals as reported by several researchers [21-27]. Aquatic plants play a vital role in harmonizing the water bodies. They naturally have the tendency to treat different wastewater streams including landfill leachate [28]. Duckweed (L. minor) is an aquatic plant that belongs to the family Lemnaceae. Owing to rapid growth rate, cold tolerance, ease of harvesting, and cost effectiveness, Lemna minor is a much better candidate than other aquatic plants for phytoextraction of heavy metals [29]. Duckweed has been reported to be very effective in the phytoextraction of organic matter, suspended solids, heavy metals, and soluble salts from wastewater [30]. In wastewater treatment studies, L. minor is used for the monitoring of heavy metals
[31]. In this study, phytoremediation potential of duckweed (L. minor), for the treatment of landfill leachate, was evaluated for 15 days. Heavy metal content and physiochemical parameters of landfill leachate were investigated.

\section{Materials and Methods}

2.1. Collection of Leachate. Raw samples of landfill leachate (LL) were randomly collected from three different points under normal weather conditions from Mehmood Booti landfill site. Mehmood Booti landfill site (Lahore, Pakistan) is located in the north side of Bund road (latitude: $31.610^{\circ} \mathrm{N}$, longitude: $74.382^{\circ} \mathrm{E}$ ) approximately 1 kilometer away from river Ravi. Leachate was collected and stored in $1000 \mathrm{ml}$ plastic cans. Temperature and $\mathrm{pH}$ of the samples were recorded in situ with the help of a portable $\mathrm{pH}$ meter (Hanna HI 2210). Samples of landfill leachate were then immediately transferred to the laboratory and stored at $4^{\circ} \mathrm{C}$ before going for further analysis. Physiochemical parameters and heavy metal contents were analyzed according to the standard methods for the examination of water and wastewater, unless otherwise stated [32].

2.2. Collection of Plant Sample. Samples of duckweed ( $L$. minor) were collected from fresh water ponds at the Fisheries Research and Training Institute, Lahore $\left(31.5890^{\circ} \mathrm{N}\right.$, $\left.74.4642^{\circ} \mathrm{E}\right)$. Plants were carefully washed with water to remove the insect larvae and epiphytes. Plant samples were put into the plastic jar, filled with water, for one week to acclimatize with the existing environment. After that, plants of the same size were collected for the research experimentation. Samples of landfill leachate and Lemna minor were collected in the month of July 2016.

2.3. Experimental Setup. One set of experimental containers, having three tubs, was arranged. Each experimental container was filled with $20 \mathrm{~L}$ landfill leachate and $200 \mathrm{~g}$ fresh weight of duckweed. Experiment was conducted in triplicate to attain the average efficiency of the plant, and the study was performed in the month of November. The mean daily temperature during the study was $23 \pm 5^{\circ} \mathrm{C}$, while daily average humidity was $72 \pm 15 \%$ at the experimental site. Test duration was $0,3,6,9,12$, and 15 days (total 6 observations with pretreatment data).

\subsection{Heavy Metal Estimation in Leachate and Plant Samples.} Plant samples were washed thoroughly before they were oven dried at $70^{\circ} \mathrm{C}$. After complete drying, plant samples were crushed and sieved to $<1 \mathrm{~mm}$. Plant samples $(0.25 \mathrm{~g}$ each) were digested with diacid $\left(\mathrm{HNO}_{3}-\mathrm{HCLO}_{4}\right)$ by gradually increasing the temperature. After complete digestion, distilled water was added in the sample to make the final volume up to $50 \mathrm{ml}$. Heavy metal $(\mathrm{Zn}, \mathrm{Pb}, \mathrm{Fe}, \mathrm{Cu}$, and $\mathrm{Ni}$ ) contents were determined in both plant and leachate samples using the atomic absorption spectrophotometer (AAS) (Z-8230). 
2.5. Calculation. Uptake of heavy metals by the plant was calculated using the dilution factor as follows:

$$
\text { dilution factor }=\frac{\text { total volume of sample }(\mathrm{ml})}{\text { weight of the plant }(\mathrm{g})} .
$$

Percentage efficiency was calculated by determining the initial ( $\mathrm{C} 0)$ and final concentration $(\mathrm{C} 1)$ of metals in the sample as described previously [33]:

$$
\text { Removal percentage }=\frac{\mathrm{C} 0-\mathrm{C} 1}{\mathrm{C} 0} * 100,
$$

where $\mathrm{C} 0$ and $\mathrm{C} 1$ are the initial and final concentration of the metal in the medium $\left(\mathrm{mg} \cdot \mathrm{L}^{-1}\right)$.

The bioconcentration factor was calculated as described previously [34]:

$$
\mathrm{BCF}=\frac{\text { metal concentration in plant }\left(\mathrm{mg} \cdot \mathrm{kg}^{-1}\right)}{\text { metal concentration in medium }\left(\mathrm{mg} \cdot \mathrm{L}^{-1}\right)} .
$$

2.6. Statistical Analysis. Data presented in this paper are the mean of three replicates \pm SD. Analysis of variance (ANOVA) and graphical representation were performed with GraphPad prism5 software followed by Tukey's test to get the significant difference between different mean values.

\section{Results and Discussion}

3.1. Physiochemical Parameters. Results of the phytoremediation potential study on Lemna minor are given in Table 1. $\mathrm{pH}$ of landfill leachate reduced from its initial value (7.9) to the final value of (6.8) by the end of 15-day experiment as depicted in Table 1. Duckweed (L. minor) has the potential to survive under a wide range of $\mathrm{pH}$, i.e., 4.5 to 7.5 [35]. Values of TSS and TDS were $63.5 \mathrm{mg} \cdot \mathrm{L}^{-1}$ and $1695 \mathrm{mg} \cdot \mathrm{L}^{-1}$, respectively, in landfill leachate. As demonstrated in Table 1, concentration of TSS was reduced with the passage of time, reaching the minimum level of $42 \mathrm{mg} \cdot \mathrm{L}^{-1}$ at the end of the experiment. Results regarding the reduction of TSS were in line with a previous study that reported a noticeable decline in resuspension of TSS in Taiho lake, covered with aquatic plants during the experimental period of 41 days [35]. Meanwhile, the least value of TDS, i.e., $986 \mathrm{mg} \cdot \mathrm{L}^{-1}$, was recorded after the 15-day experimental period. This reduction in the TDS is attributed to the plants' capacity to absorb inorganic and organic ions. The values of COD and BOD in landfill leachate were also higher than the permissible limit set by NEQS [36]. The high level of COD reveals the presence of organic contaminants and intense load of heavy metals. Both, COD and BOD showed a gradual decrease during the experiment. Results revealed that $L$. minor successfully reduced COD by 39\% (from 1899 to $756 \mathrm{mg} \cdot \mathrm{L}^{-1}$ ) and BOD by $47 \%$ (from 889 to $423 \mathrm{mg} \cdot \mathrm{L}^{-1}$ ). In agreement with the results of present research, Azeez and Sabbar [37] also reported a $32.7 \%$ and $49.6 \%$ decline in COD and BOD, respectively, during a 4 -week phytoremediation study on oil refinery by Lemna minor. Similarly, Zimmo et al. [38] reported a more efficient reduction in BOD of duckweed-based ponds than that of algal-based ones.

3.2. Heavy Metal Removal from Leachate. Results on removal of heavy metals $(\mathrm{Zn}, \mathrm{Pb}, \mathrm{Fe}, \mathrm{Cu}$, and $\mathrm{Ni}$ ) through phytoremediation of landfill leachate by Lemna minor at different time periods of exposure are shown in Figures 1-5. Reduction in concentration of heavy metals in landfill leachate depends upon the duration of exposure to L. minor. Zinc concentration of leachate was reduced from $1.47 \mathrm{mg} \cdot \mathrm{L}^{-1}$ to $0.024 \mathrm{mg} \cdot \mathrm{L}^{-1}$ during 15 -day experiment. Initial concentration of lead was $0.83 \mathrm{mg} \cdot \mathrm{L}^{-1}$ in the landfill leachate in which significant decrease $(p<0.05)$ was observed during the first 9 days, following a negligible change thereafter till the end of the experiment. A similar response of iron was observed as its initial concentration $\left(1.17 \mathrm{mg} \cdot \mathrm{L}^{-1}\right)$ was significantly reduced to $0.26 \mathrm{mg} \cdot \mathrm{L}^{-1}$ at the end of the experiment. Concentration of copper considerably declined from 0.69 to $0.06 \mathrm{mg} \cdot \mathrm{L}^{-1}$ in landfill leachate $(p<0.01)$. Concentration of nickel also significantly reduced $(p<0.05)$ from $1.21 \mathrm{mg} \cdot \mathrm{L}^{-1}$ to $0.29 \mathrm{mg} \cdot \mathrm{L}^{-1}$ after phytoremediation through Lemna minor as described in Figure 5. Overall, Lemna minor exhibited a great ability to remove all the heavy metals under study from the landfill leachate. The higher potential of L. minor to remove metals from leachate is attributed to huge biomass production and efficient growth in the highly metal-polluted environment [39].

3.3. Removal Efficiency. The present study demonstrates that metal removal efficiency of $L$. minor from landfill leachate was more than 70 to $90 \%$ (Figure 6). The maximum efficiency (91\%) of $L$. minor was observed for the removal of copper from leachate. Removal efficiency for $\mathrm{Pb}, \mathrm{Zn}, \mathrm{Fe}$, and $\mathrm{Ni}$ was $78,83,77$, and $76 \%$, respectively. A previous study reported that $L$. minor removed $76 \%$ lead and $82 \%$ nickel from the contaminated solution under laboratory conditions [25]. Metal removal efficiency of L. minor was in the following order: $\mathrm{Cu}(91 \%)>\mathrm{Zn}(83 \%)>\mathrm{Pb}(78 \%)>\mathrm{Fe}(77 \%)>$ $\mathrm{Ni}(76 \%)$. Similar results for heavy-metal removal efficiency were also reported by other researchers [21, 40]. Results of a previous study reported that that removal efficiency of $L$. minor was $58 \%, 62 \%$, and $68 \%$ for copper, lead, and nickel, respectively [41]. Similarly, $L$. minor removes nickel by $74 \%$ and lead by $79 \%$ from the industrial wastewater stream [42].

3.4. Accumulation of Heavy Metals. Heavy metal accumulation in dry biomass of plants is dependent on concentration of metals and duration of the experiment [43]. Accumulation of zinc was highest on the 6th day, following a gradual decrease with time (Figure 1). Concentration of zinc in $L$. minor was recorded as $1.15,1.17,0.99,0.95$, and $0.93 \mathrm{mg} \cdot \mathrm{kg}^{-1}$ after $3,6,9,12$, and 15 days of exposure, respectively. Similarly, in a previous study, L. minor was reported to accumulate higher amount of zinc as compared to L. gibba [44]. Zinc is an essential trace element which plays an important role in the growth and development of plants. Zinc is a most commonly found element in several enzymes 
TABLE 1: Physicochemical characteristics of landfill leachate before and after phytoremediation experiment.

\begin{tabular}{lcccc}
\hline \multirow{2}{*}{ Parameters } & Before phytoremediation & $\begin{array}{c}\text { After phytoremediation } \\
\text { Lemna minor L. }\end{array}$ & Percentage reduction & NEQS permissible limit \\
\hline $\mathrm{pH} \mathrm{mg} \cdot \mathrm{L}^{-1}$ & 7.9 & $6.8 \pm 0.24 \mathrm{~ns}$ & $13 \%$ & $6-10$ \\
$\mathrm{TSS} \mathrm{mg} \cdot \mathrm{L}^{-1}$ & 63.4 & $42.2 \pm 3.56 \mathrm{~ns}$ & $33 \%$ & 150 \\
$\mathrm{TDS} \mathrm{mg} \cdot \mathrm{L}^{-1}$ & 1695 & $986 \pm 7.68 \mathrm{~ns}$ & $41 \%$ & 3500 \\
$\mathrm{COD} \mathrm{mg} \cdot \mathrm{L}^{-1}$ & 1899 & $756 \pm 4.32 \mathrm{~ns}$ & $39 \%$ & 150 \\
$\mathrm{BOD} \mathrm{mg} \cdot \mathrm{L}^{-1}$ & 889 & $423 \pm 4.69^{*}$ & $47 \%$ & 80 \\
$\mathrm{Zn} \mathrm{mg} \cdot \mathrm{L}^{-1}$ & 1.47 & $0.24 \pm 0.02^{*}$ & $78 \%$ & 5 \\
$\mathrm{~Pb} \mathrm{mg} \cdot \mathrm{L}^{-1}$ & 0.83 & $0.18 \pm 0.04^{*}$ & $91 \%$ & 0.5 \\
$\mathrm{Cu} \mathrm{mg} \cdot \mathrm{L}^{-1}$ & 0.69 & $0.06 \pm 0.02^{* *}$ & $77 \%$ & 1 \\
$\mathrm{Fe} \mathrm{mg} \cdot \mathrm{L}^{-1}$ & 1.17 & $0.26 \pm 0.03^{*}$ & $76 \%$ & 2 \\
$\mathrm{Ni} \mathrm{mg} \cdot \mathrm{L}^{-1}$ & 1.21 & $0.29 \pm 0.02^{*}$ & 1 \\
\hline
\end{tabular}

Values are the mean of three replicates. NIQS, National Environment Quality Standards, Pakistan; ND, not detected; ns, nonsignificant. ${ }^{*, * *}$ significantly different at $p<0.05$ or $p<0.01$ level of ANOVA, respectively (mean $\pm \mathrm{SD}, n=3$ ).
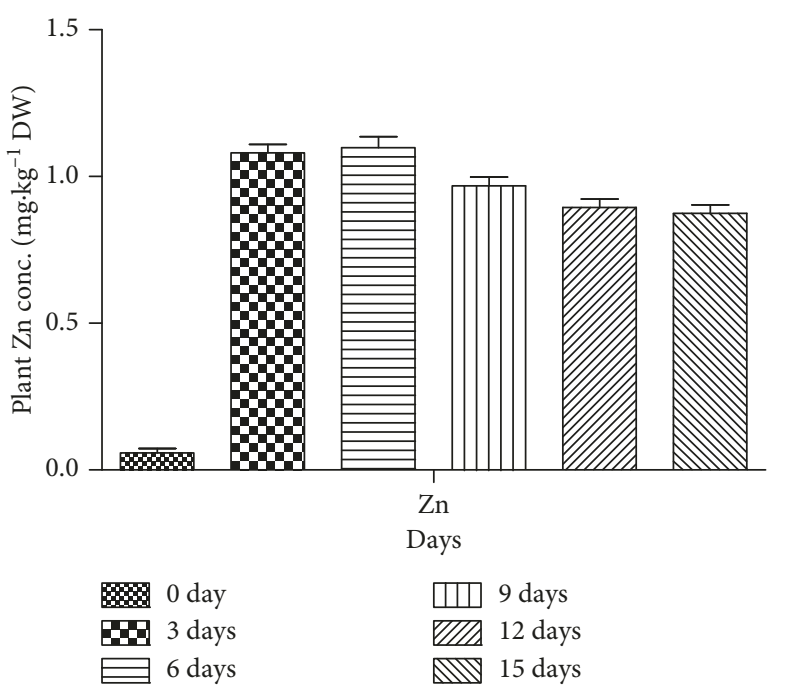

FIGURE 1: Zinc concentration in L. minor at different exposure time (days) from leachate. Bars represent standard deviation. Values are mean \pm SD of three replicates.
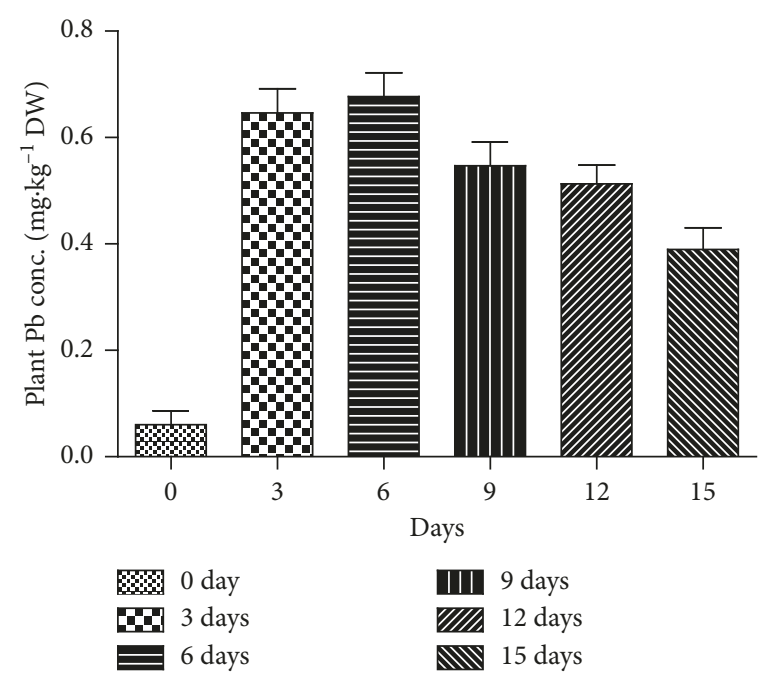

FIGURE 2: Lead concentration in L. minor at different exposure time (days) from leachate. Bars represent standard deviation. Values are mean \pm SD of three replicates.
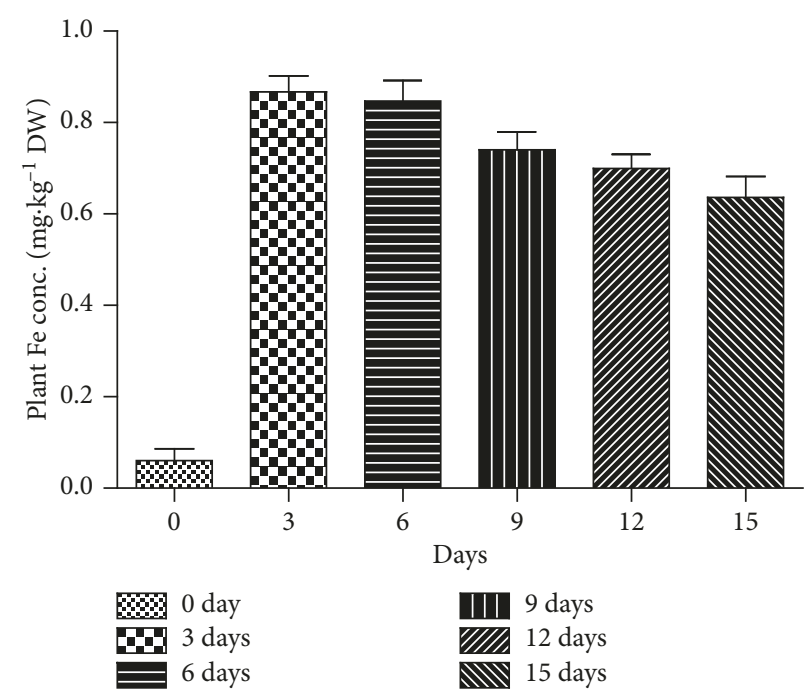

FIGURE 3: Iron concentration in L. minor at different exposure time (days) from leachate. Bars represent standard deviation. Values are mean \pm SD of three replicates.
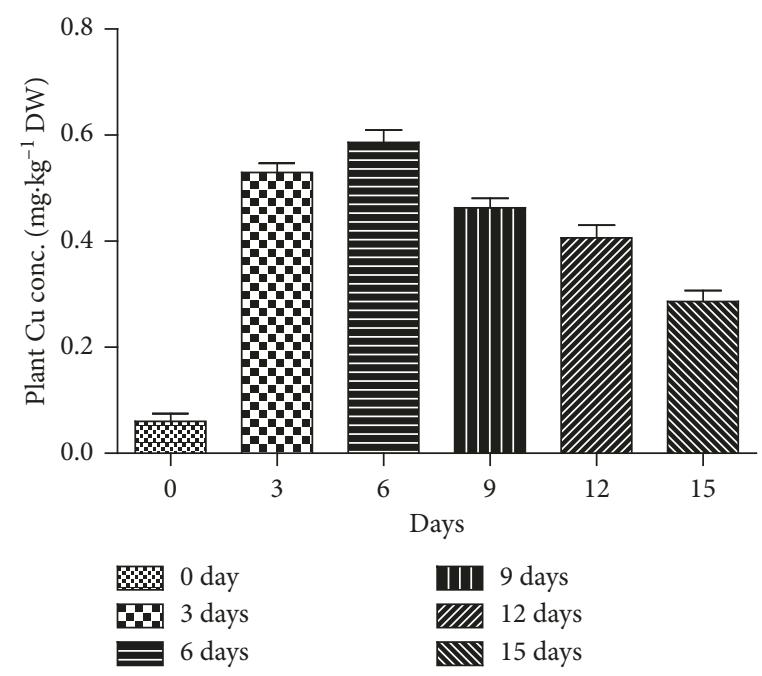

FIgURE 4: Copper concentration in L. minor at different exposure time (days) from leachate. Bars represent standard deviation. Values are mean $\pm \mathrm{SD}$ of three replicates. 


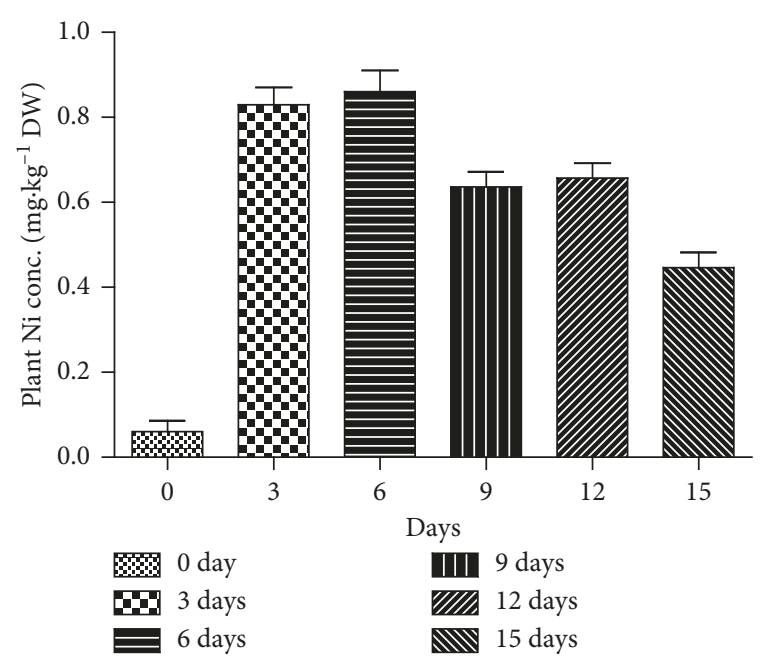

FIGURE 5: Nickel concentration in L. minor at different exposure time (days) from leachate. Bars represent standard deviation. Values are mean \pm SD of three replicates.

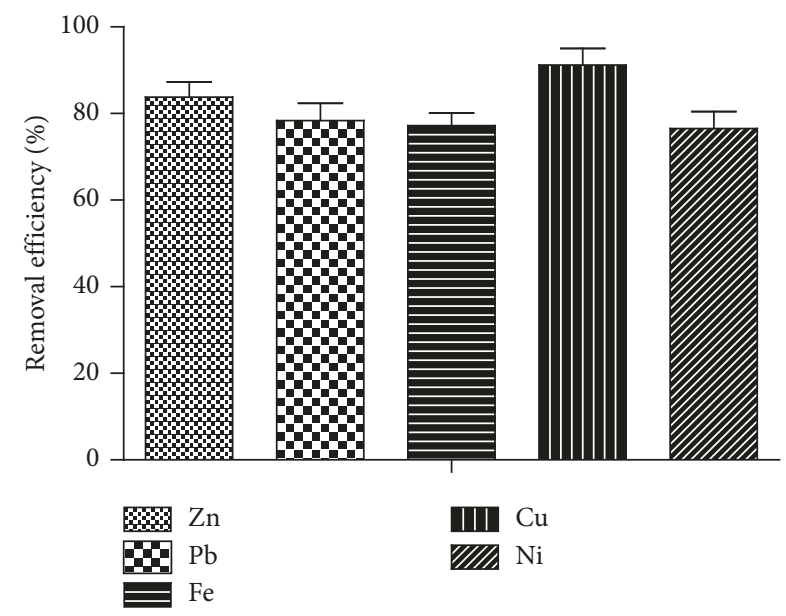

Figure 6: Percentage removal efficiency by L. minor for landfill leachate wastewater. Bars represent standard deviation. Values are mean $\pm \mathrm{SD}$ of three replicates.

such as cytochrome oxides, polyphenol oxides, and ascorbic acid oxides $[45,46]$. Upon absorption by plants, $\mathrm{Zn}$ is transformed from insoluble to soluble state $\left(\mathrm{Zn}^{2+}\right)$ which ultimately enhances the capacity of the aquatic plant to accumulate higher amount of $\mathrm{Zn}$ in their body [47]. Plants accumulated maximum concentration of lead on the 6th day of the experiment, after which minor changes occurred till the end of the experiment. Highest lead accumulation was $0.68 \mathrm{mg} \cdot \mathrm{kg}^{-1}$ on day 6 , while the least $0.39 \mathrm{mg} \cdot \mathrm{kg}^{-1}$ was observed on day 15 (Figure 2). Similar observations for the accumulation of lead by $L$. minor were also recorded by Singh et al. [19]. L. minor also accumulated $\mathrm{Pb}$ at the rate of $561 \mathrm{mg} \cdot \mathrm{kg}^{-1}$ dry weight $(\mathrm{dw})$ on day 7 of the experiment at $50 \mathrm{mg} \cdot \mathrm{L}^{-1}$ concentration in the growth medium [48].

The results of this study demonstrated that accumulation of $\mathrm{Pb}$ increased with the increase in concentration and duration of exposure. Results for accumulation of $\mathrm{Pb}$ are in line with the earlier studies on different aquatic plants like
Wolffia arrhiza, [49] Najas indica, [50] C. demersum, [51] Lemna minor, and Lemna gibba [52]. Uptake of iron by L. minor was increased gradually till the 12th day of experiment and exhibited a declining trend thereafter. Accumulation of iron on days 3 and 9 of the experiment was 0.87 and $0.74 \mathrm{mg} \cdot \mathrm{kg}^{-1}$, respectively. It was reduced to $0.64 \mathrm{mg} \cdot \mathrm{kg}^{-1}$ by the end of the treatment (Figure 3). Iron, at the same time, is equally important for the growth and development of plants. Uptake of Fe is crucial for the metabolism of chloroplast and mitochondria. Mostly iron exists in the form of less soluble ferric oxides, which becomes free of oxides at low $\mathrm{pH}$ and is converted to readily available form of $\mathrm{Fe}$ for the plants to uptake [53].

From the leachate, plants accumulated highest concentration of copper at the start of the experiment till day 9 , followed by no significant increase in its accumulation. Maximum accumulation $\left(0.58 \mathrm{mg} \cdot \mathrm{kg}^{-1}\right)$ was recorded on day 6 of the experiment (Figure 4). Copper is an essential micronutrient and plays a vital role in the growth and development of plants $[54,55]$. Plants regulate the intercellular copper level by rectifying its uptake and declining the free intercellular copper concentrations by metallochaperones. These are $\mathrm{Cu}$-binding soluble proteins which transport it to the sections of the plant cells where they are needed the most [56]. During the study, maximum concentration of nickel accumulated on days 3 and 6 of the experiment. Its concentration was 0.83 and 0.86 and $0.64 \mathrm{mg} \cdot \mathrm{kg}^{-1}$ on days 3,6 , and 9, respectively. Nickel promoted the growth and development of Lemna minor fronds when applied at the rate of $0.5 \mathrm{mg} \cdot \mathrm{L}^{-1}$ [57]. Lemna minor absorbed nickel more proficiently as compared with lead [24]. L. minor removed 65,72 and $87 \% \mathrm{Ni}$ at different initial concentrations during a twenty-two-day experimental study [58]. Similar result was also reported where L. Minor accumulated more $\mathrm{Ni}$ as compared to L. gibba after 80 days of exposure [59]. Results of the present study, for the accumulation of nickel, are in agreement with the earlier reports [60-62]. The accumulation of heavy metals by $L$. minor was in order of $\mathrm{Cu}$ $\left(0.84 \mathrm{mg} \cdot \mathrm{kg}^{-1}\right)>\mathrm{Pb}\left(0.68 \mathrm{mg} \cdot \mathrm{kg}^{-1}\right)>\mathrm{Zn}\left(1.17 \mathrm{mg} \cdot \mathrm{kg}^{-1}\right)>\mathrm{Fe}$ $\left(0.87 \mathrm{mg} \cdot \mathrm{kg}^{-1}\right)>\mathrm{Ni}\left(0.86 \mathrm{mg} \cdot \mathrm{kg}^{-1}\right)$ from the landfill leachate.

Accumulation of heavy metals by the whole plant is depicted in Figure 7. Results obtained from the present study revealed that the uptake of metal by plants was dependent upon their initial concentration in the wastewater. Findings of this study were in line with those of Axtell et al. [24]. Similarly, L. minor showed a significant phytoremediation potential by accumulating more than $90 \%$ of $\mathrm{Fe}, \mathrm{Zn}$, and $\mathrm{Cu}$ with different concentrations at different time periods [63]. Analysis of variance showed significant uptake $(p<0.05)$ of all heavy metals from landfill leachate during the experimental study.

\subsection{Bioconcentration Factor for Heavy Metals.} Bioconcentration factor is expressed as the ratio of the concentration of heavy metals absorbed by plant tissues to that in the medium [34]. Bioconcentration factor (BCF) is considered as a blueprint for the determination of metal uptake effectiveness by aquatic plants [64]. Bioconcentration 


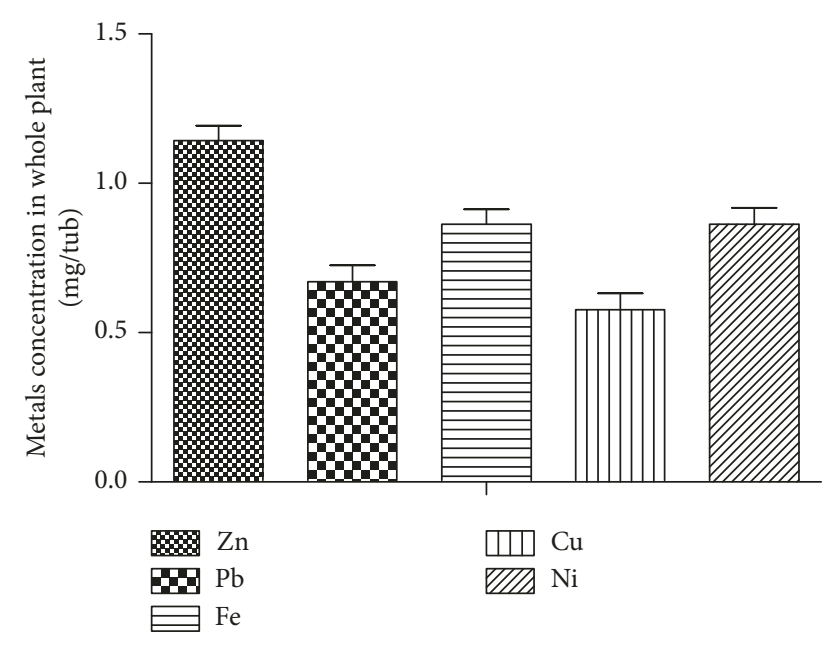

Figure 7: Metal concentration in whole plant (mg/tub). Bars represent standard deviation. Values are mean $\pm \mathrm{SD}$ of three replicates.

factor values, for the accumulation of heavy metals by $L$. minor at different exposure time periods, are given in Table 2. The maximum BCF value for zinc was 0.78 and 0.81 on the $3 \mathrm{rd}$ and 6 th day of the experiment, respectively. The bioconcentration value for lead increased progressively and attained the maximum level (0.81) on the 6th day of the experiment. From landfill leachate, BCF value for iron was the highest one on the 3rd and 6th day of experiment. BCF value for copper was $0.76,0.84,0.68,0.65$, and 0.42 on day $3,6,9,12$, and 15 of the experiment, respectively. Maximum BCF value (0.71) for nickel was observed on 6 th day of the experiment. Results indicate that L. minor, grown on the landfill leachate, showed maximum BCF values for copper, lead, and zinc. BCF values of heavy metals by $L$. minor were in the order of $\mathrm{Cu}(0.84)>\mathrm{Pb}(0.81), \mathrm{Zn}(0.81)>$ $\mathrm{Fe}(0.74)>\mathrm{Ni}(0.71)$. Similarly, BCF values for $\mathrm{Cu}, \mathrm{Ni}, \mathrm{Pb}$, and $\mathrm{Cd}$ were also found to be less than one by L. minor from two different kinds of effluents in a hydroponic experiment for 31 days [61]. In another study, L. minor came out as an excellent accumulator for $\mathrm{Fe}, \mathrm{Zn}$, and $\mathrm{Cu}$ having the $\mathrm{BCF}$ value more than 1 from different lakes in south Urals region, Russia [65].

According to previous studies, different floating aquatic plants demonstrated much higher accumulation for these heavy metals with higher bioconcentration factor. Roots of Eichhornia crassipes and Pistia stratiotes showed much better metal accumulation potential as compared to the upper parts of the plants. In this study, values of bioconcentration factor for $\mathrm{Zn}, \mathrm{Cu}$, and $\mathrm{Pb}$ were more than 1 in both aquatic plants [66]. Physiological demand of plant tissues for certain heavy metals and their accumulation kinetics directly or indirectly affects their absorption from the growth medium [67]. The value of BCF more than 1 indicates the suitability of certain aquatic plants (i.e., hyperaccumulators) for phytoextraction of heavy metals. In the current study, the BCF values of $L$. minor for all the heavy metals were found to be lower than 1 . The results suggest that $L$. minor is a moderate accumulator for
TABLE 2: Bioconcentration factor for L. minor for heavy metals at different exposure time periods from landfill leachate.

\begin{tabular}{lccccc}
\hline \multirow{2}{*}{ Sample metal } & \multicolumn{5}{c}{ Exposure time (days) } \\
& 3 & 6 & 9 & 12 & 15 \\
\hline $\mathrm{Zn}$ & 0.78 & 0.81 & 0.46 & 0.29 & 0.27 \\
$\mathrm{~Pb}$ & 0.46 & 0.81 & 0.41 & 0.37 & 0.29 \\
$\mathrm{Fe}$ & 0.63 & 0.60 & 0.44 & 0.41 & 0.30 \\
$\mathrm{Cu}$ & 0.76 & 0.84 & 0.68 & 0.65 & 0.42 \\
$\mathrm{Ni}$ & 0.58 & 0.71 & 0.37 & 0.34 & 0.25 \\
\hline
\end{tabular}

$\mathrm{Zn}, \mathrm{Cu}, \mathrm{Pb}, \mathrm{Ni}$, and $\mathrm{Cu}$ under given circumstances of the present study.

\section{Conclusion}

The present study concluded that landfill leachate was loaded with both organic and inorganic pollutants. Phytoremediation experiment of landfill leachate using $L$. minor was found to be efficient for the reduction of both organic and inorganic pollutants. The reduction in $\mathrm{pH}$, TSS, TDS, COD, BOD, $\mathrm{Zn}, \mathrm{Pb}, \mathrm{Fe}, \mathrm{Cu}$, and $\mathrm{Ni}$ was recorded during 15 days phytoremediation experiment using L. minor. The rate of removal was accelerated from the 3 rd to 9 th day of the experiment. Accumulation of heavy metals was directly proportional to their initial concentration in landfill leachate. Removal efficiency for all the metals was higher than $70 \%$. Among 5 metals under study, the accumulation of copper in L. minor was the highest one. The highest BCF values were shown by copper (0.84) and lead (0.81). Plants demonstrate extensive ability to remove heavy metals from landfill leachate. High removal efficiency and accumulation capacity of L. minor for heavy metals indicate its phytoremediation potential. This study provides a deep insight into the potential of duckweed (L. minor) to be used as a convenient and economically feasible method for the phytoremediation of metal-polluted aquatic environment on large-scale basis.

\section{Data Availability}

The data used to support the findings of this study are included within the article.

\section{Conflicts of Interest}

The authors declare that they have no conflicts of interest regarding the publication of this article.

\section{Acknowledgments}

This work was funded by the National Key Technology R\&D program of China (2016YFD0101404), the National Natural Science Fund (31501342), China Agriculture Research System (CARS-18-25), and Jiangsu Collaborative Innovation Center for Modern Crop Production. 


\section{References}

[1] F. N. Ahmed and C. Q. Lan, "Treatment of landfill leachate using membrane bioreactors: a review," Desalination, vol. 287, pp. 41-54, 2012.

[2] C. O. Akinbile, M. S. Yusoff, and A. Z. Ahmad Zuki, "Landfill leachate treatment using sub-surface flow constructed wetland by Cyperus haspan," Waste Management, vol. 32, no. 7, pp. 1387-1393, 2012.

[3] M. Umar, H. Aziz, and M. S. Yusoff, "Trends in the use of Fenton, electro-Fenton and photo-Fenton for the treatment of landfill leachate," Waste Management, vol. 30, no. 11, pp. 2113-2121, 2010.

[4] S. Renou, J. Givaudan, S. Poulain, and M. P. Dirassouyan, "Landfill leachate treatment: review and opportunity," Journal of Hazardous Material, vol. 150, no. 3, pp. 468-493, 2008.

[5] A. A. Abbas, G. Jingsong, L. Z. Ping, Y. Y. Pan, and W. S. AlRekabi, "Review on landfill leachate treatments," American Journal of Applied Sciences, vol. 6, no. 4, pp. 672-684, 2009.

[6] D. L. Jones, K. L. Williamson, and A. G. Owen, "Phytoremediation of landfill leachate," Waste Management, vol. 26, no. 8, pp. 825-837, 2006.

[7] M. L. Ward, G. Bitton, and T. Townsend, "Heavy metal binding capacity (HMBC) of municipal solid waste landfill leachate," Chemosphere, vol. 60, no. 2, pp. 206-215, 2005.

[8] S. Bozkurt, L. Moreno, and I. Neretnieks, "Long term processes in waste deposits," Science of the Total Environment, vol. 250, no. 1-3, pp. 101-121, 2000.

[9] A. S. Erses and T. T. Onay, "In situ heavy metal attenuation in landfills under methanogenic conditions," Journal of Hazardous Marterial, Part B, vol. 99, no. 2, pp. 159-175, 2003.

[10] P. Censi, S. E. Spoto, F. Saiano et al., "Heavy metals in coastal water system. A case study from the Western Gulf of Thailand," Chemosphere, vol. 64, no. 7, pp. 1167-1176, 2006.

[11] M. Topal, B. Karagözoğlu, and E. Öbek, "Planted batch system treating leachate," Nevşehir University Journal of Science and Technology, vol. 1, no. 2, pp. 87-97, 2012.

[12] P. K. Rai, "Heavy metal pollution in aquatic ecosystems and its phytoremediation using wetland plants: an eco-sustainable approach," International Journal of Phytoremediation, vol. 10, no. 2, pp. 133-160, 2008.

[13] K. R. Kim and G. Owens, "Potential for enhanced phytoremediation for landfills using biosolids-a review," Journal of Environmental Management, vol. 91, no. 4, pp. 791-797, 2010.

[14] R. Chandra and S. Yadav, "Phytoremediation of Cd, Cr, Cu, $\mathrm{Mn}, \mathrm{Fe}, \mathrm{Ni}, \mathrm{Pb}$ and $\mathrm{Zn}$ from aqueous solution using Phragmites cummunis, Typha angustifolia and Cyperous esculentus," International Journal of Phytoremediation, vol. 13, no. 6, pp. 580-591, 2011.

[15] P. Miretzky, A. Saralegui, and A. F. Cirell, "Aquatic macrophytes potential for the simultaneous removal of heavy metals," Chemosphere, vol. 57, no. 8, pp. 997-1005, 2004.

[16] M. A. Rahman and H. Hasegawa, "Aquatic arsenic: phytoremediation using floating macrophytes," Chemosphere, vol. 83, no. 5, pp. 633-646, 2011.

[17] E. P. Smits and M. Pilon, "Phytoremediation of metals using transgenic plants," Crititcal Reviews in Plant Sciences, vol. 21, no. 5, pp. 439-456, 2002.

[18] L. Marchand, M. Mench, D. L. Jacob, and M. L. Otte, "Metal and metalloid removal in constructed wetlands, with emphasis on the importance of plants and standardized measurements: a review," Environment Pollution, vol. 158, no. 12, pp. 3447-3461, 2010.
[19] D. Singh, R. Gupta, and A. Tiwari, "Potential of duckweed (Lemna minor) for removal of lead from wastewater by phytoremediation," International Journal of Food Science and Technology, vol. 2, no. 1, pp. 10-26, 2012.

[20] P. J. C. Favas and J. Pratas, "Uptake of uranium by native aquatic plants: potential for bioindication and phytoremediation," E3S Web of Conferences, vol. 1, p. 13007, 2013.

[21] V. C. Pandey, "Phytoremediation of heavy metals from fly ash pond by Azolla caroliniana," Ecotoxicology and Environmental Safety, vol. 82, pp. 8-12, 2012.

[22] A. Sood, P. L. Uniyal, R. Prasanna, and A. S. Ahluwalia, "Phytoremediation potential of aquatic macrophyte, Azolla," AMBIO, vol. 41, no. 2, pp. 122-137, 2012.

[23] A. L. Charles, S. J. Markich, and P. Ralph, "Toxicity of uranium and copper individually, and in combination, to a tropical freshwater macrophyte (Lemna aequinoctialis)," Chemosphere, vol. 62, no. 8, pp. 1224-1233, 2006.

[24] N. R. Axtell, S. P. K. Sternberg, and K. Claussen, "Lead and nickel removing using Microspora and Lemna minor," Bioresource Technology, vol. 89, no. 1, pp. 41-48, 2003.

[25] X. Zhang, Y. Hu, Y. Liu, and B. Chen, "Arsenic uptake, accumulation and phytofiltration by duckweed (Spirodela polyrhiza L.)," Journal of Environmental Science, vol. 23, no. 4, pp. 601-606, 2011.

[26] T. O. Ajayi and A. O. Ogunbayio, "Achieving environmental sustainability in wastewater treatment by phytoremediation with water hyacinth (Eichhornia crassipes)," Journal of Sustainable Development, vol. 5, no. 7, pp. 1-11, 2012.

[27] A. F. A. Baker, I. Yusoff, N. T. Fatt, F. Othman, and M. A. Ashraf, "Arsenic, zinc, and aluminium removal from gold mine wastewater effluents and accumulation by submerged aquatic plants (Cabomba piauhyensis, Egeria densa, and Hydrilla verticillata)," BioMed Research International, vol. 2013, Article ID 890803, 7 pages, 2013.

[28] M. Topal, B. Karagözoğlu, and E. Öbek, "Natural treatment of leachate," Afyon Kocatepe University Journal of Sciences, vol. 11, no. 2, pp. 1-16, 2011.

[29] W. A. El-Kheir, G. İsmail, F. A. El-Nour, T. Tawfik, and D. Hammad, "Assesment of the efficiency of duckweed (Lemna gibba) in wastewater treatment," International Journal of Agriculture and Biology, vol. 9, pp. 681-687, 2007.

[30] S. Radic, D. Stipanicev, P. Cvjetko et al., "Ecotoxicological assessment of industrial effluentusing duckweed (Lemna minor L.) as a test organism," Ecotoxicology, vol. 19, no. 1, pp. 216-222, 2010.

[31] APHA, Standard Methods for the Examination of Water and Wastewater, American Public Health Association/American Water Works Association/Water Environment Federation, Washington, DC, USA, 21st edition, 2005.

[32] P. Tanhan, M. Kruatrachue, P. Pokethitiyook, and R. Chaiyarat, "Uptake and accumulation of cadmium, lead and zinc by Siam weed (Chromolaena odorata L. King \& Robinson)," Chemosphere, vol. 68, no. 2, pp. 323-329, 2007.

[33] A. Zayed, S. Gowthaman, and N. Terry, "Phytoaccumulation of trace elements by wetland plants: I. Duckweed," Journal of Environmental Quality, vol. 27, no. 3, pp. 715-721, 1998.

[34] S. Saygideger, "Lemna gibba L.ve Lemna minor L.(Lemnaceae)' nin morfolojik anatomk, ekolojikve," Fizyzolojik Ozellikleri.Ekoloji, vol. 18, pp. 8-11, 1996.

[35] P. Huang, B. Han, and Z. Lin, "Floating-leaved macrophyte (Trapa quadrispinosa Roxb) beds have significant effects on sediment Resuspension in lake Taiho, China," Hydrobiologia, vol. 581, no. 1, pp. 189-193, 2007. 
[36] National Environmental Quality Standards (NEQS), Pakistan Environmental Legislation, Ministry of Environment, Government of Pakistan, National Environmental Quality Standards (NEQS), Pakistan, 2000.

[37] N. M. Azeez and A. A. Sabbar, "Efficiency of duckweed (Lemna minor L.) in phytotreatmen of wastewater pollutants from basrah oil refinery," Journal of Applied Phytotechnology in Environmental Sanitation, vol. 1, no. 4, pp. 163-172, 2012.

[38] O. R. Zimmo, N. P. Van Der Steen, and H. J. Gijzen, "Effect of organic surface load on process performance of pilot scale Algae and duckweed based waste stabilization ponds," Journal of Environmental Engineering, vol. 131, no. 4, pp. 587-594, 2005.

[39] C. Mant, S. Costa, J. Williams, and E. Tambourgi, "Phytoremediation of chromium by model constructed wetland," Bioresource Technology, vol. 97, no. 15, pp. 1767-1772, 2007.

[40] Z. Leblebici and A. Aksoy, "Growth and lead accumulation capacity of Lemna minor and Spirodela polyrrhiza (Lemnaceae): interactions with nutrient enrichment," Water, Air, and Soil Pollution, vol. 214, no. 1-4, pp. 175-184, 2011.

[41] A. Loveson and R. Sivalingam, "Aquatic macrophyte Spirodela polyrriza as a phytoremediation tool in polluted wetland water from Eloor, Ernakulam District, Kerala," Journal of Environmental Analytical Toxicology, vol. 5, no. 1, pp. 51-58, 2013.

[42] M. S. Al-Khafaji, F. H. Al-Ani, and A. F. Ibrahim, "Removal of some heavy metals from industrial wastewater by Lemna minor," KSCE Journal of Civil Engineering, vol. 22, no. 4, pp. 1077-1082, 2017.

[43] V. Mazzei, G. Longo, M. V. Brundo, C. Copat, G. OliveriConti, and M. Ferrante, "Effects of heavy metal accumulation on some reproductive characters in Armadillidium granulatum Brandt (Crustacea, Isopoda, Oniscidea)," Ecotoxicology and Environmental Safety, vol. 98, pp. 66-73, 2013.

[44] E. Lahive, J. Michael, A. O'Callaghan, A. Marcel, K. Jansen, and J. O'Halloran, "Uptake and partinioning of zinc in lemnaceae," Ecotoxicology, vol. 20, no. 8, pp. 1992-2002, 2011.

[45] E. Lesage, D. P. Rousseau, E. Meers, F. M. Tack, and N. De Pauw, "Accumulation of metals in a horizontal subsurface flow constructed wetland treating domestic wastewater in Flanders Belgium," Science of The Total Environment, vol. 380, no. 1-3, pp. 102-115, 2007.

[46] J. Vymazal, J. Švehla, L. Kröpfelová, and V. Chrastny, “Trace metals in phragmites australis and phalaris arundinacea growing in constructed and natural wetlands," Science of the Total Environment, vol. 380, no. 1-3, pp. 154-162, 2007.

[47] S. P. Mcgrath, Z. G. Shen, and F. J. Zhao, "Heavy metal uptake and chemical changes in the Rhizosphere of Thlaspi caerulescens and Thlaspi ochroleucum grown in contaminated soils," Plant and Soil, vol. 188, no. 1, pp. 153-159, 1997.

[48] D. D. Yilmaz and H. Akbulut, "Effect of circulation on wastewater treatment by Lemna gibba and Lemna minor (floating aquatic macrophytes)," International Journal of Phytoremediation, vol. 13, no. 10, pp. 970-984, 2011.

[49] A. Piotrowska, A. Bajguz, B. Godlewska-Zyłkiewicz, R. Czerpak, and M. Kamińska, "Jasmonic acid as modulator of lead toxicity in aquatic plant Wolffia arrhiza (Lemnaceae)," Environmental and Experimental Botany, vol. 66, no. 3, pp. 507-513, 2009.

[50] R. Singh, R. D. Tripathi, S. Dwivedi, A. Kumar, P. K. Trivedi, and D. Chakrabarty, "Lead bioaccumulation potential of an aquatic macrophyte Najas indica are related to antioxidant system," Bioresource Technology, vol. 101, no. 9, pp. 30253032, 2010.

[51] M. Chen, L. L. Zhang, J. Li, X. J. He, and J. C. Cai, "Bioaccumulation and tolerance characteristics of a submerged plant (Ceratophyllum demersum L.) exposed to toxic metal lead," Ecotoxicology and Environmental Safety, vol. 122, pp. 313-321, 2015.

[52] M. Sasmaz, E. Obek, and A. Sasmaz, "Bioaccumulation of uranium and thorium by Lemna minor and Lemna gibba in $\mathrm{Pb}-\mathrm{Zn}-\mathrm{Ag}$ tailing water," Bulletin of Environmental Contamination and Toxicology, vol. 97, no. 6, pp. 832-837, 2016.

[53] E. L. Walker and E. L. Connolly, "Time to pump iron: irondeficiency-signaling mechanisms of higher plants," Current Opinion in Plant Biology, vol. 11, no. 5, pp. 530-535, 2008.

[54] E. Mateos-Naranjo, A. Gallé, I. Florez-Sarasa et al., "Assessment of the role of silicon in the $\mathrm{Cu}$-tolerance of the $\mathrm{C} 4$ grass spartina densiflora," Journal of Plant Physiology, vol. 178, pp. 74-83, 2015.

[55] M. Wu, X. Jiang, Y. Lv et al., "Long-term effect of Cu 419 (ii) on the phosphorous removal performance in enhanced biological phosphorous 420 removal systems," Chemical Engineering Journal, vol. 281, pp. 164-173, 2015.

[56] O. Halloran, T. V. Culotta, and V. C. Metallochaperones, “An intracellular shuttle service for 422 metal ions," Journal of Biological Chemistry, vol. 275, no. 33, pp. 25057-25060, 2000.

[57] C. Goswami and A. Majumder, "Potential of Lemna minor in $\mathrm{Ni}$ and Cr removal from aqueous solution," Pollution, vol. 1, no. 4, pp. 373-385, 2015.

[58] C. Goswami, A. Majumder, A. K. Misra, and K. Bandyopadhyay, "Arsenic uptake by Lemna minor in hydroponic system," International Journal of Phytoremediation, vol. 16, no. 12, pp. 1221-1227, 2014.

[59] A. Sasmaz, I. M. Dogan, and M. Sasmaz, "Removal of Cr, Ni and $\mathrm{Co}$ in the water of chromium mining areas by using Lemna gibba L. and Lemna minor L," Water and Environment Journal, vol. 30, no. 3-4, pp. 235-242, 2016.

[60] L. Kaur, K. Gadgil, and S. Sharma, "Comparative evaluation of salicylic acid and EDTA chelant induced phytoremediation of lead and nickel using Lemna minor L.," Tropical Plant Research, vol. 2, no. 3, pp. 264-270, 2015.

[61] S. H. Bokhari, I. Ahmad, M. Mahmood-Ul-Hassan, and A. Mohammad, "Phytoremediation potential of Lemna minor L. for heavy metals," International Journal of Phytoremediation, vol. 18, no. 1, pp. 25-32, 2016.

[62] Y. Gopalapillai and B. A. Hale, "Internal versus external dose for describing ternary metal mixture $(\mathrm{Ni}, \mathrm{Cu}, \mathrm{Cd})$ chronic toxicity to Lemna minor," Environmental Science \& Technology, vol. 51, no. 9, pp. 5233-5241, 2017.

[63] R. Othman, R. Ramya, Z. M. Baharuddin, K. S. Has-Yun Hashim, and M. Yaman, "Response of Lemna minor and Salninia natans as phyroremediation agents towards $\mathrm{Fe}, \mathrm{Cu}$ and $\mathrm{Zn}$ toxicities via in vivo model system," Jurnal Teknologi, vol. 77, no. 30, pp. 101-109, 2015.

[64] F. Duman, Z. Leblebici, and A. Aksoy, "Bioaccumulation of nickel, copper, and cadmium by Spirodela polyrhiza and Lemna gibba," Journal of Freshwater Ecology, vol. 24, no. 1, pp. 177-179, 2009.

[65] T. G. Krupnova, I. V. Mashkova, A. M. Kostryukova, N. O. Egorov, and S. V. Gavrilkina, "Bioconcentration of heavy metals in aquatic macrophytes of South Urals region lakes," Biodiversitas Journal of Biological Diversity, vol. 19, no. 1, pp. 296-302, 2018.

[66] K. K. Victor, M. Ladji, A. O. Adjiri, Y. D. A. Cyrille, and T. A. Sanogo, "Bioaccumulation of heavy metals from 
wastewaters $(\mathrm{Pb}, \mathrm{Zn}, \mathrm{Cd}, \mathrm{Cu}$ and $\mathrm{Cr})$ in water hyacinth (Eichhornia crassipes) and water lettuce (Pistia stratiotes)," International Journal of ChemTech Research, vol. 9, no. 2, pp. 189-195, 2016.

[67] R. Verma and S. Suthar, "Lead and cadmium removal from water using duckweed-Lemna gibba L.: impact of $\mathrm{pH}$ and initial metal load," Alexandria Engineering Journal, vol. 54, no. 4, pp. 1297-1304, 2015. 

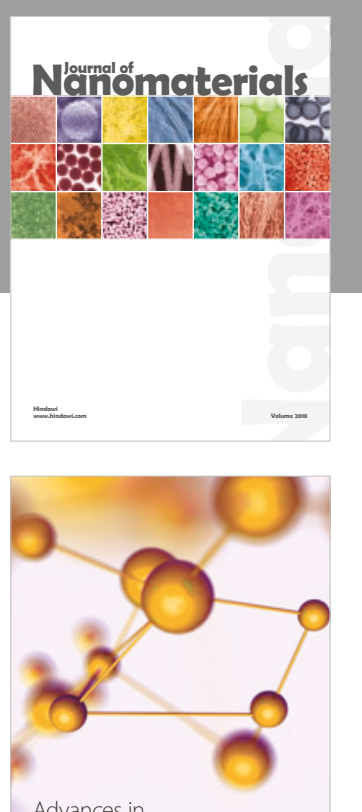

Physical Chemistry
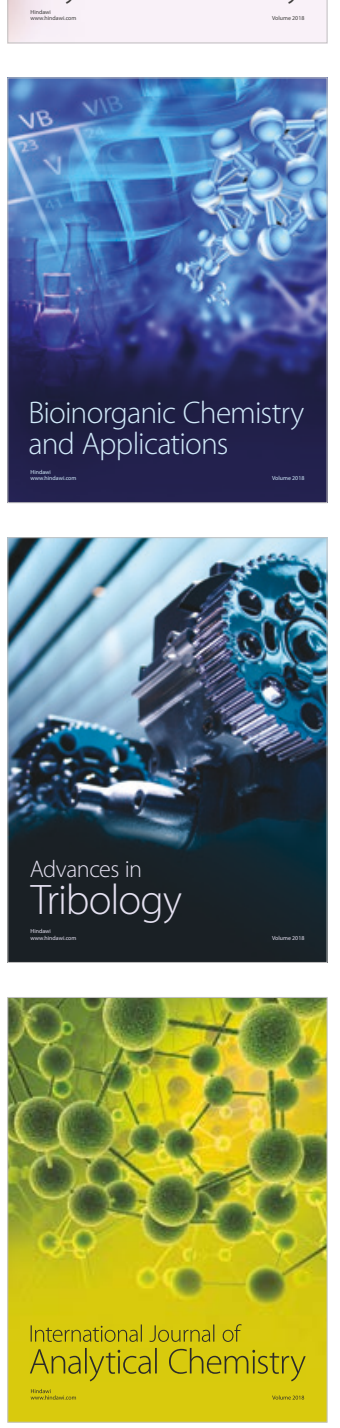

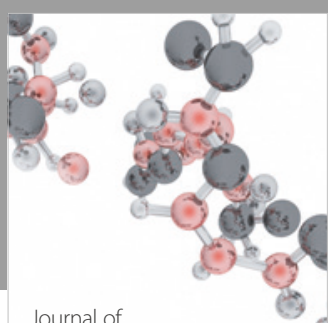

Analytical Methods

in Chemistry

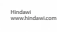

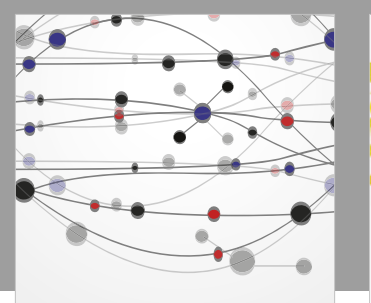

The Scientific World Journal

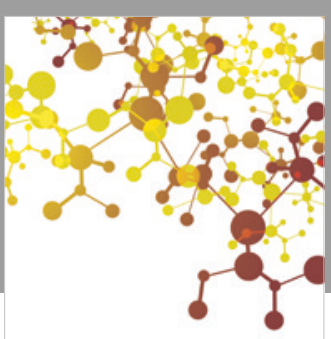

Journal of

Applied Chemistry
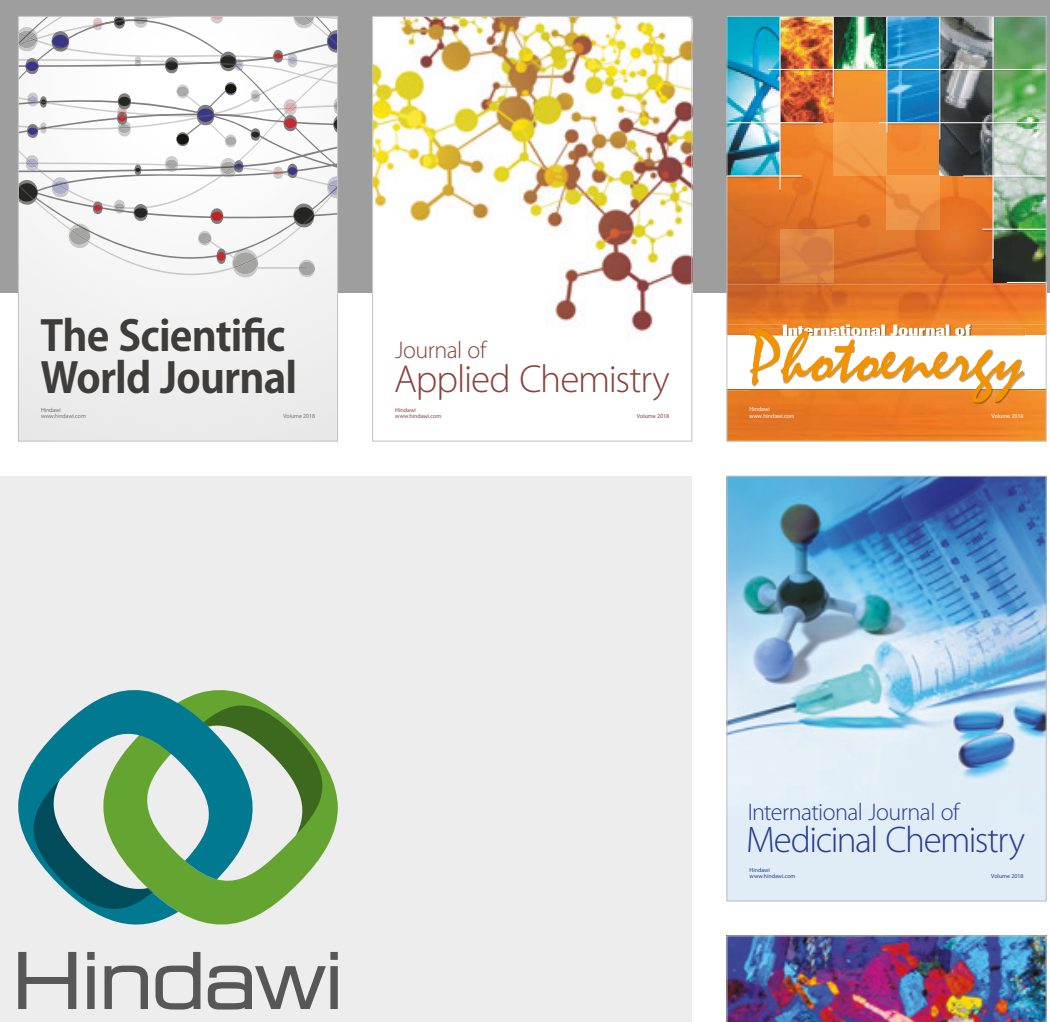

Submit your manuscripts at

www.hindawi.com
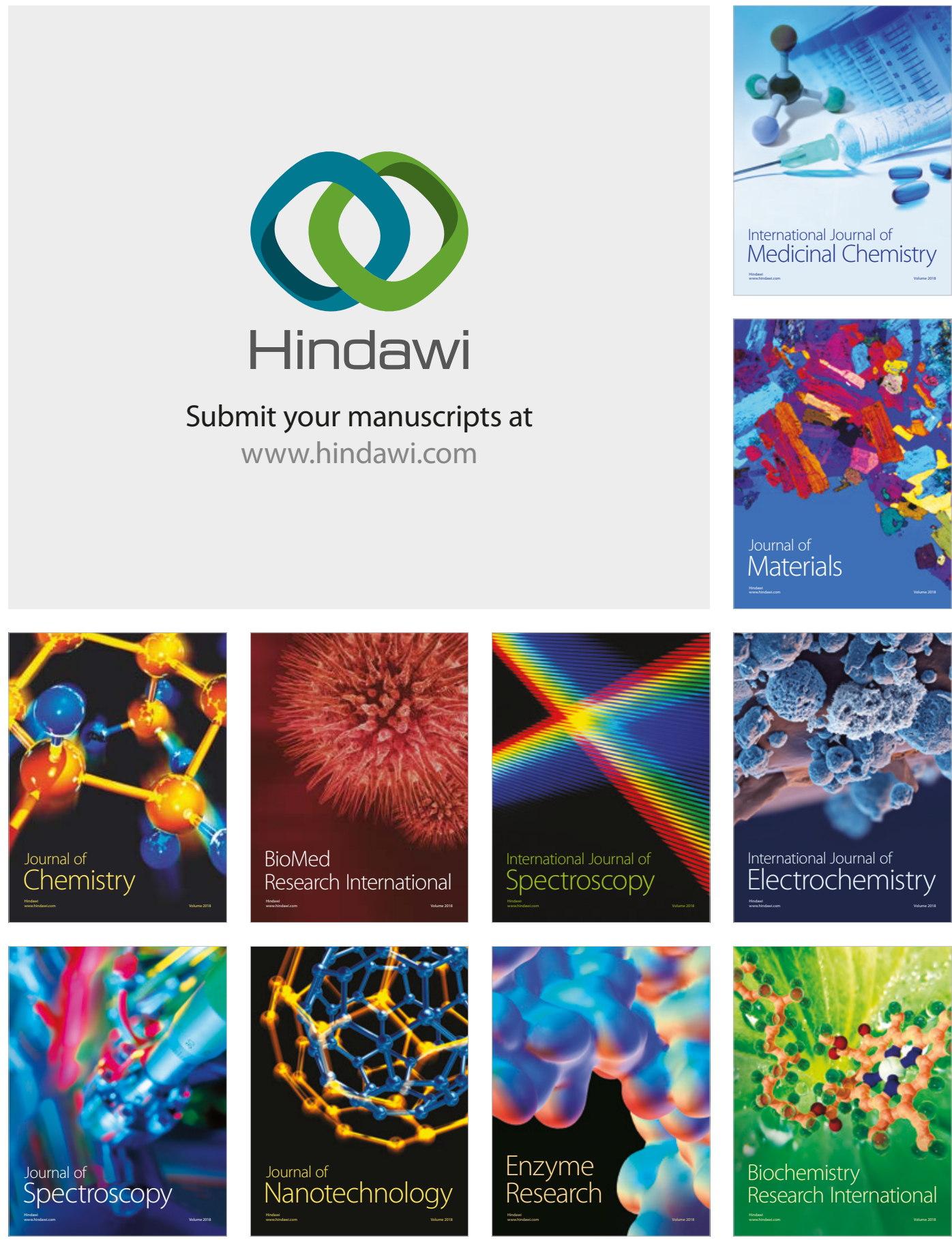
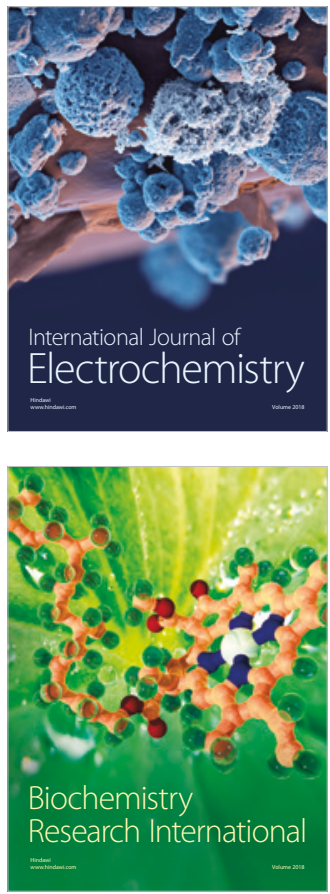